\title{
PENGEMBANGAN DESA SENTRA ORGANIC FARMING DI DESA RENDENG, GEBANG, PURWOREJO
}

\author{
Budi Setiawan'1), Zulfanita²), Didik Widiyantono ${ }^{3)}$, Sugeng Eko Putro Widoyoko4)

\begin{abstract}
1)Program Studi Hukum Fakultas IImu Sosial Universitas Muhammadiyah Purworejo
3) Program Studi Agribisnis Fakultas Pertanian Universitas Muhammadiyah Purworejo

4)Program Studi Pendidikan Ekonomi FKIP Universitas Muhammadiyah Purworejo
\end{abstract} \\ 2)Program Studi Peternakan Fakultas Pertanian Universitas Muhammadiyah Purworejo \\ Corresponding author : Budi Setiawan \\ E-mail : budi.setiawan@umpwr.ac.id
}

\section{Diterima 24 September 2020, Direvisi 10 Oktober 2020, Disetujui 12 Okober 2020}

\begin{abstract}
ABSTRAK
Kesadaran petani akan dampak dari penggunaan pupuk atau pestisida kimia dalam pertanian konvensional sangat rendah. Penurunan kualitas lingkungan seperti berkurangnya serangga, penurunan kesuburan tanah, penurunan kualitas air, udara dan polusi tanah disebabkan oleh penggunaan bahan kimia dalam pertanian konvensional. Salah satu yang dapat dijadikan solusi untuk mengatasi kondisi ini adalah pengembangan pertanian organik (organic farming). Program Pengabdian Masyarakat dilaksanakan di desa Rendeng, kecamatan Gebang, kabupaten Purworejo bertujuan untuk menjadikan desa Rendeng sebagai kawasan pertanian, peternakan dan perikanan berbasis organic farming. Mitra dalam pelaksanan pengabdian masyarakat ini adalah kelompok tani Ngudi Makmur dengan anggota 30 orang. Metode yang digunakan adalah Education for Sustainable Development (EfSD) merupakan salah satu metode pengabdian kepada masyarakat yang berorientasi pada penyelesaian masalah pada lingkungan masyarakat. Metode EfSD menekankan pada 3 pilar yaitu ekonomi, ekologi atau lingkungan dan sosial. Program kegiatan yang dilaksanakan secara garis besar meliputi, 1) pemberdayaan masyarakat melalui penguatan kelembagaan dan peningkatan kualitas sumber daya manusia,2) Penumbuhan dan pengembangan budidaya pertanian, dan perikanan berbasis organic farming, 3) peningkatan produksi, pengolahan dan pemasaran hasil pertanian dan perikanan. Hasil pengabdian masyarakat ini berupa penguatan kelembagaan Kelompok Tani Ngudi Makmur beraktifitas dengan aktif, adanya program kegiatan dan sosialisasi serta pelatihan serta pembinaan pengetahuan dan pengalaman kelompok tani dalam pengembangan pertanian dan perikanan organik.
\end{abstract}

Kata kunci : organic farming; pertanian; perikanan; education for sustainable development.

\begin{abstract}
Farmers' awareness of the impact of using chemical fertilizers or pesticides in conventional agriculture is very low. Environmental quality degradation such as reduced DR, decreased air quality, air pollution is caused by the use of chemicals in conventional agriculture. One of the solutions to overcome this condition is the development of organic agriculture (organic farming). The Community Service Program implemented in Rendeng village, Gebang District, Purworejo Regency aims to make Rendeng village an organic agriculture-based agricultural, livestock and fishery area. Partners in implementing this community service are the Ngudi Makmur farmer group with 30 members. The method used is Education for Sustainable Development (EfSD), which is a community service method that is oriented towards solving problems in the community environment. The EfSD method emphasizes 3 pillars, namely economic, ecological or environmental and social. The program of activities carried out in outline includes, 1) community empowerment through institutional strengthening and improvement of the quality of human resources, 2) cultivation and development of agricultural and fisheries based on organic agriculture, 3) increasing production, processing and marketing of agricultural and fishery products. The results of this community service are in the form of institutional strengthening of the Ngudi Makmur Farmer Group to be actively active, the existence of a program of activities and outreach as well as training as well as fostering knowledge and experience of farmer groups in developing organic agriculture and fisheries.
\end{abstract}

Keywords : organic farming; agriculture; fishery; education for sustainable development. 


\section{PENDAHULUAN}

Pertanian merupakan sumber nutrisi utama bagi masyarakat seluruh dunia. Hampir tiga perempat penduduk di negara berkembang bergantung pada pertanian. Ini adalah salah satu aspek utama pembangunan manusia. Pertanian sangat penting bagi Indonesia karena menyediakan sumber mata pencaharian bagi sebagian besar penduduk dan berkontribusi terhadap PDB nasional. Dalam dekade terakhir, revolusi hijau telah membawa beberapa perubahan signifikan dalam sistem produksi pangan dunia seperti peningkatan produksi dan produktivitas pangan, pendapatan dari pertanian telah meningkat dan kesempatan kerja telah terdiversifikasi di negara maju dan berkembang (Joshi et al., 2007).Pada saat bersamaan revolusi hijau juga membawabeberapa konsekuensi agro ekologis. (David Tilman et al., 2002)(Pretty et al., 2011).Konsekuensi agroekologis ini memiliki dampak yang kurang menguntungkan bagi sumber daya petani miskin (Rosset, 2000). Revolusi hijau juga telah berkontribusi dalam deklinasi sumber daya alam (Espinel, 2008) dan menciptakan beberapa masalah lingkungan (Singh, 2000)(D. Tilman et al., 2001).

Sebagian besar pertanian yang dikembangkan di Indonesia adalah pertanian modern. Pertanian modern dicirikan dengan sistem usahatani yang menggunakan bahanbahan kimia yang berbahaya bagi kesehatan dan lingkungan. Sutanto (2002) menyatakan bahwa paket teknologi pertanian modern yang dimaksud adalah penggunaan varietas unggul berproduksi tinggi, pestisida kimia, pupuk kimia/sintesis, dan menggunakan mesin-mesin pertanian untuk mengolah tanah dan memanen hasil. Pertanian modern itu sendiri merupakan salah satu wujud dari revolusi hijau yang mulai diterapkan di Indonesia pada tahun enam puluhan. Pada awalnya revolusi hijau berhasil mengatasi kerawanan pangan sehingga Indonesia berhasil mencukupi sendiri kebutuhan pangannya yang sebelumnya Indonesia adalah negara pengimpor beras (Sutanto, 2002). Wolf (1986) dalam Sutanto (2002) juga menyatakan bahwa kenaikan produksi pangan dunia sejalan dengan penggunaan pupuk kimia. Namun, seiring dengan berjalannya waktu banyak pakar lingkungan menyadari bahwa penggunaan bahan kimia tersebut dapat menimbulkan dampak negatif berupa penurunan produktivitas tanah akibat penggunaan pupuk kimia serta rusaknya keseimbangan ekosistem akibat penggunaan pestisida. Keadaan tersebut akhirnya mendorong individu dan kelompok organisasi menyuarakan gerakan untuk mempraktikkan usahatani alami yang ramah lingkungan dengan berbagai istilah seperti "organic" atau "alternatif" dan selanjutnya berkembang menjadi pertanian organik seperti saat ini. Prospek ekonomis dari pertanian ini pun cukup baik teriring dengan berubahnya pola konsumsi manusia dimana manusia lebih memilih makanan yang sehat meskipun harganya mahal (Soetrisno, 1999).

Istilah pertanian organik dalam bahasa Indonesia merupakan terjemahan langsung dari istilah organic agriculture dan organic farming yang ditemui dalam literatur-literatur berbahasa Inggris (Saragih, 2008). Istilah pertanian organik menyebabkan petani dan konsumen untuk menghindarkan bahan kimia dan pupuk yang meracuni lingkungan dengan tujuan untuk memperoleh kondisi lingkungan yang sehat. Mereka juga berusaha untuk menghasilkan produksi tanaman yang berkelanjutan dengan cara memperbaiki kesuburan tanah menggunakan sumber daya alami seperti mendaur-ulang limbah pertanian (Sutanto, 2002). Pertanian organik adalah salah satu sistem pertanian yang ramah lingkungan. Pertanian organik merupakan pertanian yang berwawasan lingkungan karena dalam pengolahannya menggunakan bahan organik yang akan menunjang dan menjaga kesuburan tanah, serta mengembalikan kerusakan tanah akibat pertanian anorganik. Menurut Codex dalam Saragih (2008) pertanian organik adalah kegiatan pertanian yang mengupayakan penggunaan asupan luar yang minimal dan menghindari penggunaan pestisida dan pupuk sintetik. Pertanian organik merupakan pertanian yang berwawasan lingkungan karena dalam pengolahannya menggunakan bahan organik yang akan menunjang dan menjaga kesuburan tanah, serta mengembalikan kerusakan tanah akibat pertanian anorganik. Indonesia merupakan negara ketiga di Asia dalam pengembangan pertanian organik setelah China dan India (Winarno dalam Siahaan 2009). Berdasarkan data Statistik Pertanian Organik Indonesia (SPOI) yang diterbitkan oleh Aliansi Organis Indonesia (AOI), sampai tahun 2011 tercatat bahwa luas area pertanian Indonesia tahun 2011 adalah 225062.65 ha dengan status 90135.5 ha merupakan area tersertifikasi pertanian organik, 3.8 area dalam proses sertifikasi pertanian organik dan 134917.66 ha merupakan area tanpa sertifikasi organik (Ariesusanty, L., Nuryanti, S., \& Wangsa, 2010). Sangat disayangkan, jika dibandingkan tahun lalu, luas lahan ini mengalami penurunan sebesar $5.77 \%$, terutama karena menurunnya luas area pertanian organik tersertifikasi. 
Berkurangnya luas area pertanian organik menunjukkan bahwa jumlah petani dan luas lahan organik di Indonesia masih rendah. Hal ini didukung oleh data hasil lapangan pada bulan Januari hingga Maret 2017 yang menunjukkan bahwa jumlah petani organik di Kabupaten Purworejo masih sangat sedikit dibandingkan petani konvensional. Padahal menurut Saragih (2008), sejak tahun 2000, pemerintah sudah mulai mengembangkan pertanian organik di 20 kabupaten, antara lain Bogor, Sukabumi, Cianjur, Sragen, Yogyakarta, Malang dan Cimande, serta Bengkulu. Keadaan ini menunjukkan kondisi yang bertolak belakang dengan tingginya permintaan konsumen atas pertanian organik. Menurut Sutanto (2002) istilah sistem pertanian organik menghimpun seluruh imajinasi petani dan konsumen yang secara serius dan bertanggung jawab menghindarkan bahan kimia dan pupuk yang bersifat meracuni lingkungan dengan tujuan untuk memperoleh kondisi lingkungan yang sehat. Selain itu, IFOAM menyampaikan bahwa pertanian organik ini sangat tepat untuk diterapkan karena sangat aman bagi kesehatan serta teknologi pertanian yang ramah lingkungan. Dengan demikian, pertanian organik secara tidak langsung telah menjadi gaya hidup masyarakat yang selalu ingin mengkonsumsi produk-produk yang sehat dan bebas dari bahan kimia.

Desa Rendeng adalah salah satu desa penghasil produk pangan khususnya beras di kabupaten Purworejoilakukan untuk menel prospek pertanian organik khususnya beras organik, sayuran organic, buah organik dan ikan organik. Makalah ini akan memaparkan pengembangan pertanian di Rendeng, menganalisis proses hasil panen dan produk yang prospektif dan mengetahui prospek pertanian organik di desa Rendeng.

\section{METODE}

Metode yang digunakan adalah Education for Sustainable Development (EfSD) merupakan salah satu metode pengabdian kepada masyarakat yang berorientasi pada penyelesaian masalah pada lingkungan masyarakat. Metode EfSD menekankan pada 3 pilar yaitu ekonomi, ekologi atau lingkungan dan sosial. Program kegiatan yang dilaksanakan secara garis besar meliputi, 1) pemberdayaan masyarakat melalui penguatan kelembagaan dan peningkatan kualitas sumber daya manusia,2) Penumbuhan dan pengembangan budidaya pertanian, dan perikananberbasis organic farming, 3) peningkatan produksi, pengolahan dan pemasaran hasil pertanian dan perikanan. Pelaksanaan Pengabdian Masyarakat dilaksanakn di Desa Rendeng Kecamatan Gebang Kabupaten Purworejo dengan Mitranya adalah kelompok tani Ngudi Makmur Desa Rendeng dengan jumlah anggota sebanyak 30 orang.

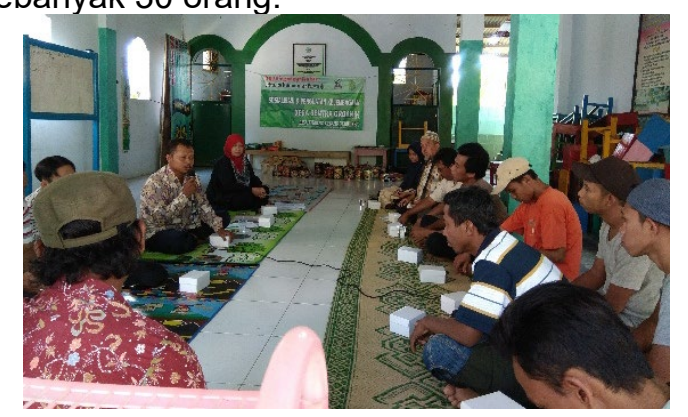

Gambar 1. Pra Dengan Kelompok Masyarakat

\section{HASIL DAN PEMBAHASAN \\ Karakteristik Demografi}

Berdasarkan data profil desa 2016, jumlah penduduk Desa Rendeng adalah 1.377 orang dan jumlah kepala keluarga yang tercatat sebanyak 415 kepala keluarga. Status kewarganegaraan seluruh penduduk Desa Rendeng adalah Warga Negara Indonesia (WNI) dengan rincian berdasakan jenis kelamin yaitu 697 orang laki-laki dan 1.377 orang perempuan (BPS, 2016). Mayoritas penduduk Rendeng merupakan penduduk asli Suku Jawa. Dari data profil Desa Rendeng 2016 juga didapatkan informasi sumber penghasilan utama sebagian besar penduduk adalah pertanian dengan komoditas utama berupa padi. Jumlah keluarga pertanian di Desa Rendeng sebanyak 215 keluarga dan terdapat keluarga yang anggota keluarganya menjadi buruh tani sebanyak 174 keluarga. Kepadatan penduduk di desa ini mencapai $1.920 \mathrm{jiwa} / \mathrm{km}^{2}$. Mata pencaharian masyarakat di Desa Rendeng cukup beragam, namun sebagian besar penduduk bermata-pencaharian sebagai petani dan buruh tani. Selain sektor pertanian, masyarakat Desa Rendeng juga bekerja di bidang wiraswasta yang meliputi usaha warung, di bidang jasa, dan pertukangan.

\section{Karakteristik Wilayah}

Desa Rendeng memiliki prasarana umum yang disediakan untuk mempermudah kehidupan sehari-hari penduduknya. Desa Rendeng terdapat balai desa balai pertemuan, dan gardu jaga. Sarana pemerintahan desa terdiri dari balai desa, jalan desa, balai pertemuan, serta gardu jaga. Desa Rendeng pada saat ini telah memiliki gedung pendidikan, yaitu gedung taman kanak-kanak (TK), gedung sekolah dasar (SD).

Gambar 2 pada Peta menunjukkan lokasi Pengabdian di Desa Rendeng dengan 
Keadaan jalan dan akses yang sudah cukup baik dengan kondisi wilayah yang datar serta jalan yang sudah beraspal ataupun bersemen. Akses transportasi menuju desa ini juga sangat mudah karena dapat dilalui oleh bus, truk, kendaraan beroda empat, maupun kendaraan beroda dua. Namun, fasilitas kendaraan umum menuju Desa Rendeng masih sangat terbatas jumlahnya dan hanya beroperasi pada jam-jam tertentu. Sehingga mayoritas penduduknya menggunakan ojek atau kendaraan pribadi, baik roda dua maupun roda empat. Penerangan di desa ini sudah relatif bagus meski beberapa titik desa masih gelap. Jarak dari Desa Rendeng ke ibukota Kecamatan Gebang sejauh $2 \mathrm{~km}$ dengan lama jarak tempuh dengan kendaraan bermotor adalah 5 menit. Jarak dari Desa Rendeng ke ibukota kabupaten/kota adalah $8 \mathrm{~km}$ dengan lama jarak tempuh menggunakan kendaran bermotor adalah 15 menit.

Sebagian besar luas wilayah desa digunakan untuk area persawahan, baik sawah bersertifikat organik maupun yang belum bersertifikat organik. Selain itu, tanah di Desa Rendeng dimanfaatkan untuk pemukiman, fasilitas umum, lapangan olahraga, dan kuburan. Desa Rendeng juga terdapat kandang ternak desa, yaitu lahan yang sengaja dimanfaatkan oleh penduduk setempat untuk dijadikan kandang hewan ternak mereka. Semua penduduk yang memiliki hewan ternak berupa sapi, kerbau, maupun kambing harus "mengandangkan" hewan mereka di kandang tersebut. Langkah tersebut dilakukan sebagai upaya untuk menjaga kebersihan lingkungan.

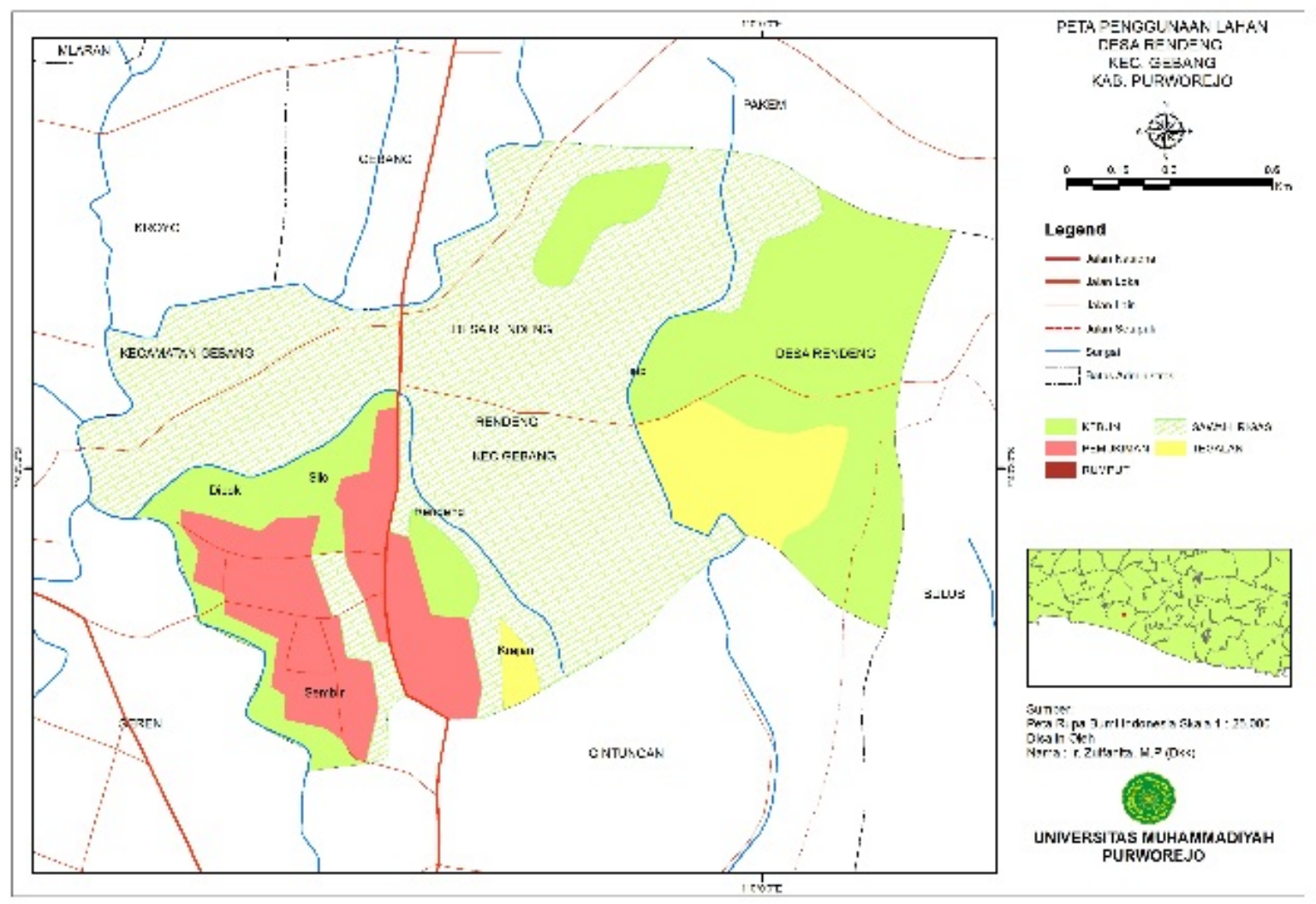

Gambar 2. Peta Penggunaan Lahan di desa Rendeng.

\section{Kondisi Ekonomi dan Pertanian}

Mata pencaharian masyarakat di Desa Rendeng cukup beragam, yaitu sebagai petani maupun di sektor lainnya yang meliputi usaha warung, bekerja di bidang jasa, dan pertukangan, baik di dalam desa maupun di luar desa. Namun, sebagian besar penduduk bermatapencaharian sebagai petani sehingga setiap kepala keluarga memiliki lahan untuk diolah, baik lahan tersebut merupakan milik pribadi, bagi hasil, sewa, maupun tanah milik pemerintah desa.. Bagi yang tidak memiliki lahan dan tidak memiliki keahlian lain, biasanya mereka menjadi buruh tani di lahan-lahan milik tetangganya. Petani di Desa Rendeng terdiri dari 288 orang. Sebanyak 46 orang petani di desa tersebut merupakan petani sekaligus pemmbudidaya ikan dan sisanya merupakan buruh petani.

Hasil pertemuan dan penyuluhan pada PRA ( Partisipatory Aktif) yang disampaikan pada Gambar 1 bahwa desa Rendeng terdapat kelompok tani dan kelompok pembudidaya ikan, namun kelompok-kelompok tersebut tidak 
aktif. Menurut penuturan DN (45 tahun), secara umum hampir seluruh petani di desa ini telah mendapatkan informasi mengenai pertanian organik, namun masih sedikit petani yang mencoba untuk menerapkan dan memiliki lahan bersertifikat organik. Namun untuk budidaya perikanan organik, hampir semua petani belum mendapatkan informasi maupun pelatihan terkait perikanan organik.

Siklus tanam di Desa Rendeng cukup beragam, tergantung kebijakan yang dibuat oleh masing-masing kelompok. Mayoritas petani di Desa Rendeng merupakan petani gurem sehingga hasil dari pertanian mereka hanya cukup untuk konsumsi pribadi. Tetapi terdapat pula beberapa petani yang menjual hasil panen mereka, baik kepada penggilingan gabah yang berada di jalan utama desa maupun kepada penangkar benih. Sedangkan untuk kelompok petani pembudidaya ikan, ratarata masih secara konvensional dan menggunakan kolam tidak permanen.

\section{Prospek Pertanian Organik}

Usaha budidaya perikanan organik, sayur organi dan buah organik adalah budidaya pertanian yang baru diperkenalkan yang ternyata memiliki sumber pendapatan yang baik. Produksi perikanan dan buah sudah cukup populer dikalangan petani desa Rendeng. Ada juga beberapa usahatani lainnya yang bisa membangkitkan penghidupan masyarakat. Ini mencakup pemeliharaan cacing sutera, budidaya jamur tiram, dan unggas. Status peternakan prospektif ini disajikan secara singkat pada tabel 1 .

Tabel 1. Prospek Pertanian Organik di desa Rendeng

\begin{tabular}{|c|c|c|c|}
\hline No & Jenis Budidaya & Status & Alasan Pendukung \\
\hline 1 & $\begin{array}{l}\text { Perikanan } \\
\text { Organik }\end{array}$ & $\begin{array}{l}\text { - Belum mulai dijual } \\
\text { - Memiliki prospek yanng bagus } \\
\text { dalam kurun 2-3 tahun kedepan. } \\
\text { - Petani memiliki keterampilan } \\
\text { dalam budidaya ikan baik } \\
\text { pembenihan } \\
\text { pembesaran. }\end{array}$ & $\begin{array}{l}\text { - Sumber air tersedia terutama aliran } \\
\text { air tawar, kolam dan kecil mata air; } \\
\text { - Permintaan pasar yang tinggi di } \\
\text { baik di kawasan Purworejo maupun } \\
\text { diluar Purworejo. }\end{array}$ \\
\hline 2 & Sayur Organik & $\begin{array}{l}\text { - Banyak potensi sayuran tersedia } \\
\text { di desa Rendeng. } \\
\text { - Belum dibudidayakan }\end{array}$ & $\begin{array}{l}\text { - Kondisi iklim yang kondusif; } \\
\text { - Jarak antar desa ke } \\
\text { dekat kota pasar kurang; } \\
\text { - Minat petani terhadap budidaya } \\
\text { sayuran organik }\end{array}$ \\
\hline 3 & Buah Organik & $\begin{array}{l}\text { - Banyak potensi buah yang bisa } \\
\text { tumbuh di kawasan desa } \\
\text { Rendeng; } \\
\text { - Belum dibudidayakan }\end{array}$ & $\begin{array}{l}\text { - Tempat pemeliharaan yang } \\
\text { memadai seperti pekarangan dan } \\
\text { lahan mati; } \\
\text { - Orang menghindari pupuk kimia } \\
\text { dan sebagian besar rumah tangga } \\
\text { telah berhenti menggunakan bahan } \\
\text { kimia. }\end{array}$ \\
\hline 4 & Peternakan & $\begin{array}{l}\text { - Sebagian rumah tangga sampel } \\
\text { yang terlibat dalam pemeliharaan } \\
\text { unggas; } \\
\text { - Hampir semua masyarakat tani } \\
\text { desa Rendeng memilihara } \\
\text { unggas. }\end{array}$ & $\begin{array}{l}\text { - Permintaan yang tinggi; } \\
\text { - Belum ada budidaya peternakan } \\
\text { berbasis organik; } \\
\text { - Hasil peternakan akan berubah ke } \\
\text { organik. }\end{array}$ \\
\hline 5 & Jamur Tiram & $\begin{array}{l}\text { - Hanya 1-2 budidaya Jamur Tiram; } \\
\text { - Hanya untuk konsumsi rumah; }\end{array}$ & $\begin{array}{l}\text { - Pertanian akan berubah menjadi } \\
\text { organik; } \\
\text { - Tempat pemeliharaan yang } \\
\text { memadai. }\end{array}$ \\
\hline
\end{tabular}

Sumber : Diolah dari hasil lapangan 2017.

\section{SIMPULAN DAN SARAN}

Pengabdian masyarakat ini dilakukan di desa Rendeng dengan tujuan untuk menemukan model pertanian organik dan pemasaran produk organik. Temuan keseluruhan menunjukkan bahwa pertanian organik dapat dilakukan di desa Rendeng.
Terlepas dari bahan kimia yang digunakan, perilaku yang terus meningkat untuk menghindari bahan kimia dan memelihara ikan telah menambahkan prospek pertanian organik di Rendenng. Selain itu, sumber daya hayati dan minat petani yang ada bersama-sama menyumbang kemungkinan pertanian dan 
perikanan organik di masa depan. Karena desa Rendeng kekurangan fasilitas jalan, produksi ikan, padi, sayuran dan buah-buahan hanya sebatas konsumsi rumahan. Masalah yang terkait dengan irigasi dan penyakit telah membatasi pertanian dan perikanan dalam skala komersial. Namun, ada beberapa aspek yang bisa dipertimbangkan untuk memperbaiki status usahatani dari tempat tersebut. Berikut rekomendasi yang dibuat untuk mencapai hasil. Rekomendasi pengabdian masyarakat ini adalah sebagai berikut:

- Menurut perspektif pemasaran, selain beras organik dan perikanan organik, produk pertanian lainnya perlu dieksplorasi di desa Rendeng, seperti buah dan sayur organik.

- Sebelum melanjutkan pertanian organik, orang-orang di Rendeng perlu dilatih mengenai konsep dan pengembangan keterampilan. Demikian juga, mereka perlu menyadari efek berbahaya dari pupuk kimia dan pestisida.

- Strategi pemasaran khusus perlu dibentuk atau dikembangkan untuk mempertahankan pertanian organik dalam jangka panjang. Ada beberapa tantangan dan masalah yang perlu diidentifikasi dan dinilai sehingga bisa mengembangkan strategi yang sesuai.

- Pertanian prospektif yang dijelaskan di atas perlu diinisiasi atau diperluas agar petani diberi dukungan khusus dalam hal pengembangan keterampilan dan pemasaran.

- Untuk pengelolaan berkelanjutan, masyarakat harus difasilitasi dengan bimbingan teknis di setiap tahap kegiatan pertanian.

\section{DAFTAR RUJUKAN}

Ariesusanty, L., Nuryanti, S., \& Wangsa, R. (2010). Statistik Pertanian Organik Indonesia. Aliansi Organis Indonesia AOI.

Espinel, R. L. (2008). Multifunctionality in Peasant Agriculture: a means of Insertion into Globalization. 1-14.

Joshi, P., Gulati, A., \& Jr, R. C. (2007). Agricultural diversification in South Asia: Beyond food security. Agricultural Diversification and ....

Paull, J. (2010). From France to the world: The international federation of organic agriculture movements (IFOAM). Journal of Social Research and Policy.

Pretty, J., Toulmin, C., \& Williams, S. (2011). Sustainable intensification in African agriculture. International Journal of Agricultural Sustainability. https://doi.org/10.3763/ijas.2010.0583

Rosset, P. (2000). The multiple functions and benefits of small farm agriculture in the context of global trade negotiations 1 . Development (Basingstoke). https://doi.org/10.1057/palgrave.develo pment.1110149

Saragih, S. E. (2008). Pertanian Organik Solusi Hidup Harmoni dan berkelanjutan. Penebar Swadaya.

Shiva, V. (1992). The violence of the Green Revolution: Third World agriculture, ecology and politics. The Violence of the Green Revolution: Third World Agriculture, Ecology and Politics. https://doi.org/10.2307/2760145

Singh, R. B. (2000). Environmental consequences of agricultural development: A case study from the green revolution state of Haryana, India. Agriculture, Ecosystems and Environment. https://doi.org/10.1016/S01678809(00)00219-X

Sutanto, R. (2002). Pertanian organik: menuju pertanian alternatif dan berkelanjutan. Kanisius.

Tilman, D., Fargione, J., Wolff, B., D’Antonio, C., Dobson, A., Howarth, R., Schindler, D., Schlesinger, W. H., Simberloff, D., \& Swackhamer, D. (2001). Forecasting agriculturally driven global environmental change. Science. https://doi.org/10.1126/science.105754 4

Tilman, David, Cassman, K. G., Matson, P. A., Naylor, R., \& Polasky, S. (2002). Agricultural sustainability and intensive production practices. In Nature. https://doi.org/10.1038/nature01014

The National List of Allowed and Prohibited Substances, Code of Federal Regulations (2017). 